Pamiętnik Literacki 2020, 2, s. 83-99

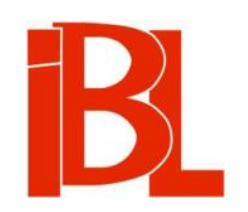

\title{
"Zuzanna" Kochanowskiego na manowcach twórczości oralnej
}

\author{
Roman Krzywy
}


Pamiętnik Literacki CXI, 2020, z. 2, PL ISSN 0031-0514

DOI: $10.18318 / \mathrm{pl} .2020 .2 .6$

ROMAN KRZYWY Uniwersytet Warszawski

\section{„ZUZANNA” KOCHANOWSKIEGO NA MANOWCACH TWÓRCZOŚCI ORALNEJ}

W zeszycie 4 „Pamiętnika Literackiego” z 2018 r. ukazał się artykuł Doroty Vincůrkovej „Zuzanna” Jana Kochanowskiego wobec konwencji wernakularnych pieśni hagiograficznych ${ }^{1}$. Jak informuje początkowa adnotacja, praca powstała pod opieką naukową Witolda Wojtowicza. Jest to patronat nieprzypadkowy, gdyż badacz już od jakiegoś czasu tropi w wybranych tekstach średniowiecznych konwencje i formy myślenia charakterystyczne dla kultury oralnej ${ }^{2}$. W niedużym studium Vincůrková zdaje się podążać w podobnym kierunku, przy czym skupia się na jednym z juweniliów Jana z Czarnolasu. Autorka dowodzi, po pierwsze, że renesansowy twórca imitował w Zuzannie poetykę polskojęzycznych pieśni o świętych i stosował ,typowo oralne środki wyrazu" (s. 70), a po drugie - że jest to tekst kunsztowny. Ponieważ jej konstatacje nierzadko pozostaja w opozycji do moich koncepcji ${ }^{3}$, poczułem się uprawniony do przedstawienia uwag polemicznych. Skłania mnie do tego zarówno brak przekonania do pomysłów Vincưrkovej, jak i ranga pisarza, którego znaczenie dla rozwoju poezji polskiej wymaga - jak sądzę - należytej staranności w literaturoznawczych rozpoznaniach.

\section{Problem kunsztu poetyckiego}

„Utwór Kochanowskiego nie jest - by posłużyć się słowami Romana Krzywego "poematem programowo niekunsztownym" (s. 70). Formułując przytoczone przez moją oponentkę twierdzenie, odwoływałem się do fragmentu $\mathrm{z}$ adresowanego do Elżbiety z Szydłowieckich Radziwiłłowej listu dedykacyjnego:

Przywiodłem ci Zuzannę, po prostu przybrana,

Dokąd jej kosztowniejszej szaty nie dostaną. [w. 9-10] ${ }^{4}$

1 Do artykułu tego odsyłam podając w nawiasie numery stronic.

2 Np. W. W o j tow i c z: Między oralnościa a pismem. Kilka uwag o staropolskiej „Legendzie o św. Aleksym”. „Pamiętnik Literacki” 2007, z. 2; Pomiędzy oralnościa a piśmiennością: tzw. „Carmen Mauri” (XII-XVI stulecie). Problemy historii tekstu epickiego i jego recepcji. „Historia Slavorum Occidentis” 2013, nr 2; Konstruowanie Galla. Problem oralności jako problem interpretacyjny tekstu. „Litteraria Copernicana” 2016, nr 3. Zawarte w owych studiach tezy budzą jednak zastrzeżenia metodologiczne, o których szerzej piszę w drugiej części niniejszej polemiki.

3 Zob. R. Krzywy, Sztuka wyborów i dar inwencji. Studium o strukturze gatunkowej poematów Jana Kochanowskiego. Warszawa 2008, s. 21-31.

4 Wszystkie cytaty z utworów poety według edycji: J. Kochanowski, Dzieła polskie. Oprac. J. Krzyża now s ki. Wyd. 11. Warszawa 1982. 
Wersy te zawierają w moim odczuciu deklarację dotyczącą literackiego kształtu utworu - deklarację, której nie powinno się lekceważyć. Nie sugeruje ona, że w parafrazie materii biblijnej zaniedbana została strona artystyczna; uzmysławia raczej zachowanie umiaru w posługiwaniu się środkami wyrazu, w operowaniu aluzjami do literatury starożytnej (jak przekonują choćby analizy Odprawy posłów greckich, Fraszek lub Trenów, Kochanowski potrafił w tym celować) czy w piętrzeniu odniesień filozoficznych ${ }^{5}$. Istotnie, przesłanie poematu nie stanowi większego wyzwania intelektualnego, wyczerpuje się bowiem w zadaniach właściwych egzemplum etycznemu. Wykonanie zaś - starałem się to wykazać w swojej książce - jest zgodne $z$ renesansowymi kanonami twórczymi, co nadaje parafrazie formę, która mamy prawo kojarzyć $z$ estetyką klasycyzującą (przestrzeganie reguły decorum, zastosowanie konwencji epickich wypracowanych przez antycznych poetów i retorów, charakterystyczne uszczegółowienie narracji, ale także posłużenie się, choć w ograniczonym zakresie, techniką imitacyjną).

Vincůrková nie zajmuje się deklaracją Kochanowskiego i to, oczywiście, ułatwia jej polemikę, ale naraża ją też na zarzut nierzetelnej prezentacji zagadnienia. Nie jest tak, że badaczka w ogóle nie zauważa listu dedykacyjnego. Przeciwnie, stanowi on dla niej istotne źródło informacji, pozwalające wnioskować o dostosowaniu poematu do „horyzontu literackiego adresatki utworu” (s. 67). Autorka artykułu, traktując ten horyzont jako typowy dla większości ówczesnych kobiet (które, ponieważ nie poznały łaciny, mogły obcować głównie z twórczością wernakularna), przypuszcza, że Kochanowski zamierzał imitować „”oralne" cechy treściowe i formalne" (s. 68), by dostosować swój poemat do świadomości artystycznej księżnej. Skupmy się najpierw na przedstawionych przez badaczkę wyznacznikach kunsztowności poematu.

O dążeniu poety do okazania własnej maestrii świadczyć ma przede wszystkim swobodne podejście do materii biblijnej, które pozwoliło mu skracać lub rozszerzać opowieść o Zuzannie o „dowolne wątki” (s. 71). Tyle że historia żony Joachima jest jednowątkowa i taka też pozostaje w przeróbce Kochanowskiego - a zatem z pewnością nie o tego rodzaju zabiegi chodziło autorowi parafrazy ${ }^{6}$.

Jako przykład amplifikacji Vincưrková podała dotyczące miłości zwroty gnomiczne (które wskazałem w swojej książce), uważając je za typowo retoryczne epifonemy ${ }^{7}$. Według badaczki ich zastosowanie dowodzi - charakterystycznych dla

5 Aby nie zostać posądzonym o dowolność, pozwolę sobie przypomnieć, iż w Wydaniu Pomnikowym wers „Dokąd jej kosztowniejszej szaty nie dostaną” F. Ła g o w s k i opatrzył komentarzem: „dopóki się kto nie postara o kosztowniejszą dla niej szatę, to jest o wiersz wytworniejszy” (J. K o c h anowski, Dzieła wszystkie. T. 2. Warszawa 1884, s. 201). Nadmienić trzeba, że już apologeci wczesnochrześcijańscy uznali styl prosty (humilis) za adekwatny do materii biblijnej. Obszernie traktuje o tym E. A u e r b a c h w pracy Język literacki $i$ jego odbiorcy $w$ późnym antyku łacińskim i średniowieczu (Przeł. R. U r bańs ki. Kraków 2006, s. 29-64).

$6 \quad$ Brak precyzji terminologicznej nie jest przedmiotem mojej polemiki, ale muszę zwrócić uwagę, że uznanie podania biblijnego, które poeta wziął na warsztat, za „tekst hagiograficzny” (s. 71) to nadużycie. Takie utożsamienie koresponduje, rzecz jasna, z tezami o nawiązaniu przez Kochanowskiego do poetyki pieśni o świętych, lecz stanowi ewidentną pomyłkę.

7 Zob. Krzywy, op. cit., s. 26. Inaczej charakter owych zwrotów oceniła K. Zi e m b a (ZZuzanna” i gatunki. W zb.: Wyobraźnia epok dawnych: obrazy - tematy - idee. Materiały sesji dedykowanej Profesorom Jadwidze i Edmundowi Kotarskim. Red. J. K. Golińs ki. Bydgoszcz 2001, s. 119), 
humanistów parających się piórem - wysokiej kultury słowa i zdolności do „twórczej imitacji mistrzów”, w przypadku zaś autora Zuzanny: „retorycznego przygotowania, elokwencji” i starań o to, by łączyć „tradycyjną kulturę wernakularną ze świadomością poetycką autora renesansowego" (s. 72).

Inkrustowanie własnych wypowiedzi (poetyckich, oratorskich, dydaktycznych, naukowych) sentencjami o rozmaitym rodowodzie nie świadczyło jednak o elokwencji czy o wysokich kompetencjach artystycznych. Taka predylekcja wynikała z podstawowego uposażenia warsztatowego każdego adepta sztuk wyzwolonych. Wykorzystania maksym uczono od czasów starożytnych już na etapie wstępnych ćwiczeń retorycznych ${ }^{8}$, postrzegano je przy tym jako podstawowy środek zwłaszcza piśmiennictwa doradczego i wychowawczego czy oratorstwa sądowego ${ }^{9}$, ale również jako topos (w znaczeniu myśli ogólnej powiązanej $z$ jakimś tematem lub $z$ określona dziedziną życia), który - poruszając konkretną kwestię - można było rozwinąć bądź jedynie przywołać ${ }^{10}$, w końcu zaś jako ornament ożywiający dyskurs. O takim pragmatycznym użytkowaniu rozmaitego rodzaju gnom traktują Jadwiga Czerwińska i Magdalena Koźluk w zacytowanym przez Vincůrkovą passusie, a także Ann Moss, znana badaczka zagadnienia, w przytoczonym omówieniu (s. 71-72).

$\mathrm{Z}$ identycznym zastosowaniem zwrotów sentencjonalnych spotykamy się w Zuzannie: są to zwroty powiązane $z$ dziedziną miłości, dotyczące właśnie poruszanego tematu, wyrażaja prawdy uniwersalne, lecz ich treść nie wykracza poza komunały. Wykorzystanie maksym nie służy żadnej grze intelektualnej, nie implikuje dialogu filozoficznego, nie stanowi też o wyrafinowanym nawiązaniu, którego odkrycie dowodziłoby rzeczywistego zamiaru poety, by zamanifestować swój kunszt.

kojarząc je $z$ topiką elegijną. Odnalezienie przeze mnie klasycznego źródła jednej z maksym - poeta zaczerpną ją z opowiedzianej w Przemianach Owidiusza historii Pyrama i Tyzbe - każe brać pod uwagę nie tyle kontekst elegijny, ile topikę miłosną w ogóle.

8 Na temat wprowadzającego kursu retoryki w dawnym szkolnictwie zob. B. B. Awianowicz, Progymnasmata $w$ teorii i praktyce szkoły humanistycznej od konca XV do połowy XVIII wieku. Dzieje nowożytnej recepcji Aftoniosa od Rudolfa Agricoli do Johanna Christopha Gottscheda. Torun 2008. Przekład niezwykle popularnego podręcznika Aftonios a Sofisty (Wstępne ćwiczenia retoryczne) można odnaleźć w tomie: Progymnasmata. Greckie ćwiczenia retoryczne i ich modelowe opracowanie. Oprac., przekł., koment. H. P o d bi el s ki. Lublin 2013. Jako jeden z elementarnych instrumentów dydaktycznych zwroty sentencjonalne - obok innych niewyszukanych form - radził stosować preceptorom książąt E r a z m z Rot t e r d a mu (Wychowanie księcia chrześcijańskiego. W: Pisma moralne. Wybór. Przeł., oprac. M. Cy t o w s ka. Warszawa 1970, s. 151): „Niekiedy dobrze posłużyć się sentencją, czasem bajką, czasem przypowieścią, innym razem stosownie dobranymi przykładami, apoftegmatem czy przysłowiem. Trzeba ryć je na pierścieniach, malować na ścianach, pisać na tablicach herbowych".

9 Zob. np. J. Górski, De generibus dicendi / O rodzajach wymowy. Wyd., przeł. R. S aw a. Red. nauk. A. Axer. Warszawa 2010, s. 79: „Wobec jednego sędziego należy przemawiać w sposób niski i prosty, na forum sądu publicznego zaś używać słów wzniosłych, "miejsc wspólnych", wykrzyknień i całego tego aparatu retorycznego, który naśladuje gnomy".

10 O zastosowaniu ich w tej funkcji pisał cytowany chętnie przez Vincưrkovą badacz twórczości ustnej, W. J. Ong (Oralność i piśmienność. Stowo poddane technologii. Przekł., wstęp J. J a pola. Lublin 1992, s. 152-153): „loci communes czy komunały odnoszą się do zbioru powiedzeń [...] na różne tematy - w rodzaju lojalności, dekadencji, przyjaźni itd. - które można zużytkować we własnym mówieniu lub pisaniu. W tym znaczeniu loci communes można nazwać "komunałami zbiorczymi»”. Zob. też A. Moss, Ksiażki „miejsc wspólnych” w szkole. Przeł. Marta S kwa ra. W zb.: Retoryka. Red. Marek Skwara. Gdańsk 2008, s. 169-170. 
Kochanowski potrafił w ten sposób posługiwać się zwrotami gnomicznymi ${ }^{11}, \mathrm{z}$ pewnościa jednak nie jest to przypadek omawianego poematu.

Przed ponad półwieczem Jerzy Ziomek zauważył, że pierwsza część skierowanej do Zuzanny przemowy zauroczonych jej urodą starców „zawiera przymilne słowa i dworną elegancję" ${ }^{2}$. Autorka artykułu rozwija to spostrzeżenie, sugerując, iż przemowa leciwych zalotników wykazuje „inspiracje poezją dworska”, ponieważ nosi znamiona „wytwornego języka miłości” (s. 72). Warto przytoczyć ów fragment poematu:

\footnotetext{
Nie lękaj się, piękna pani, sługi swoje widzisz,

Za które się nigdy, da Bóg, sprawnie nie powstydzisz;

Jedno nam nie chciej być trudna, którzy cię miłujem,

A dla ciebie niewymowną w sercu boleść czujem.

Czas po temu masz i miejsce, drzwi zawarte stoja,

Żywy człowiek nas nie widzi, pomóż łaską swoją. [w. 73-78]
}

Faktycznie, w wersach tych dostrzec można motywy typowe dla dworskiej kurtuazji, której zasady skłaniały zalotników, by przedstawiali się jako słudzy adresatek perswazji erotycznych bądź też prawili o trawiącym ich niewymownym cierpieniu. W moim przekonaniu jednak wyznanie rozgrzanych pożądaniem starców bardziej niż z poezją dworską należy kojarzyć z zachowaniami subwersyjnymi, właściwymi komicznym ujęciom tematu zalotów. Parafrazując wersety z Księgi Daniela - jak słusznie przypomniała Vincůrková (s. 72-73) - poeta złagodził wymowę oryginału, w którym starcy domagają się bez ogródek zaspokojenia cielesnego $^{13}$. Badaczka twierdzi, że może to świadczyć o zamiarze dostosowania utworu do doświadczeń kulturowych adresatki, której nieobce były maniery dworskie. Ponadto posłużenie się przez poetę rzeczownikiem „łaska” na oznaczenie zbliżenia seksualnego dowodzić ma celowej gry językiem erotycznym i religijnym, ponieważ „słowo to wzbudzać mogło w czytelniku skojarzenia z łaską Bożą” (s. 73).

Powiedzieć o ostatnim domyśle, że zaskakuje - to mało. Trudno sobie w ogóle wyobrazić, by czytelnik poematu, w którym Opatrzność nie stanowi przedmiotu libertyńskich kpin, lecz bez wątpienia jest ujęta z najwyższą powagá, mógł skojarzyć łaskę Bożą $z$ cudzołóstwem. Jeśli $z$ kolei autorka rzeczywiście dostrzega w omawianym fragmencie „zabawę $z$ konwencją dworskiej miłości” (s. 73), nader stosowne byłoby wyjaśnienie, na czym ta gra polega, gdyż samą sugestię trudno przyjąc za dobra monetę.

Nie przekonują również twierdzenia, że Elżbieta Radziwiłłowa to odbiorca wirtualny utworu i że komponenty świata przedstawionego są skorelowane $z$ jej horyzontami kulturowymi czy doświadczeniami dworskimi. Przypisanie dzieła literackiego jakiejkolwiek osobie wcale nie musiało oznaczać tego rodzaju uzgodnień i nic

11 Zob. na ten temat instruktywne prace J. Ax e r a: Rola kryptocytatów z literatury łacińskiej w polskojęzycznej twórczości Jana Kochanowskiego. „Pamiętnik Literacki” 1982, z. 1/2; Tradycja klasyczna $w$ polskojęzycznej poezji renesansowej a mechanizmy odbioru tej poezji. Jw., 1984, z. 2.

12 J. Zi o m e k, O „Zuzannie” Jana Kochanowskiego. W zb.: Ze studiów nad literatura staropolska. Red. K. Budzyk. Wrocław 1957, s. 133.

13 Zwrócił na to uwage już A. F e i w przyczynku Jana Kochanowskiego zwroty pospolite i wytworne („Slavia Occidentalis” t. $12\langle 1933\rangle$, s. 122). 
nie wskazuje na to, by taki był cel starań Kochanowskiego. Ani język rodzimy nie może być tu żadną wskazówką (przypomnijmy, że współczesne Zuzannie utwory polskojęzyczne Jana z Czarnolasu, takie jak Szachy czy Satyr abo Dziki mą̇, zostały przypisane mężczyznom), ani domniemane horyzonty księżnej - o których $\mathrm{w}$ gruncie rzeczy niewiele wiemy. Ofiarowanie poematu młodej, liczącej w roku publikacji 28 lub 29 lat, żonie litewskiego magnata (o jego względy najprawdopodobniej autor zabiegał) świadczy raczej o związkach klientalnych niż o zabiegach $\operatorname{artystycznych}^{14}$.

Mimo spersonalizowanego przypisania utwór ogłoszony drukiem był kierowany przecież do szerokiej publiczności literackiej, nie do jednej osoby. I to z werdyktem wykształconych odbiorców na temat wykonanej pracy poetyckiej autor liczył się, jak sądzę, znacznie bardziej. Złagodzenie słownictwa występującego w podstawie parafrazy i odwołanie się do frazeologii dwornej należy łączyć - jak w przypadku zwrotów gnomicznych $-\mathrm{z}$ kategoriami tematu oraz stosowności. Prezentując tematykę miłosną, twórca posługiwał się właściwymi formułami, których użycie nakazywały mu tradycja rzymska i romańska, a także reguła decorum. Analogicznie postapił przedstawiając w nieco późniejszej Pamiątce Janowi Baptyście, hrabi na Tęczynie dzieje uczucia, jakie tytułowy bohater żywił do szwedzkiej królewny Cecylii ${ }^{15}$. Trzeba również nadmienić, że - jak zauważył niedawno Bartosz Awianowicz zbliżona frazeologia występuje w tym samym kontekście w XV-wiecznym włoskim poemacie o Zuzannie pióra florenckiej autorki Lucrezii Tornabuoni (La istoria della casta Susanna), który najprawdopodobniej znany był Kochanowskiemu i stanowił dla niego jedno ze źródeł inspiracji podczas pisania utworu ${ }^{16}$. Badaczka, chociaż przywołuje artykuł Awianowicza (s. 70-71, przypis 35), nie napomyka o tej paranteli - chyba dlatego, że osłabiałoby to jej tezę o kunsztowności polskiej Zuzanny.

Polegająca na uzgodnieniu opowieści biblijnej z konwencjami klasycznymi zmiana paradygmatu estetycznego motywuje wystarczająco wprowadzenie również innych amplifikacji. Zgodnie $\mathrm{z}$ tym kanonem twórczym Kochanowski poszerzył fabułę o partie opisowe (bądź dodając deskrypcje, bądź je rozwijając), rozbudował ją też o nocne soliloquium bohaterki. Pierwsze stanowiły wymóg epickiej narratio, z kolei nokturn - dla którego można znaleźć odpowiedniki w tradycji literackiej daje się rozpatrywać również w nawiązaniu do reguł retorycznej etopei (nb. także wchodzącej w skład ćwiczeń wstępnych przygotowujących do nauki sztuki wymowy). Nie jest prawdą, że omawiając te kwestie, nie zważam na „zwyczaje wczesno-

Na temat wykształcenia Radziwiłłowej nie mamy bliższych informacji, wiemy jednak, że jej rodzice dbali o edukację dzieci. Jak przypuszczał S. Kot (Nieznany poeta polski XVI wieku. „Zeitschrift für Slavische Philologie” t. 25 〈1956〉, nr 1, s. 116), „wyniosła [ona] z domu rodzinnego wielka ogładę i wykształcenie polskie". Dowodzi tego chociażby jej korespondencja z królewnami Katarzyną i Anną Jagiellonkami - zob. J. Ki e s z k ow s ki, Kanclerz Krzysztof Szydłowiecki. Z dziejów kultury i sztuki Zygmuntowskich czasów. Poznań 1912, s. 276, 309-312.

15 Zob. Kr zywy, op. cit., s. 204-205. Również i w tym utworze znalazło się miejsce na zaczerpniętą z Owidiusza sentencję o miłości. Myśl z w. 168: „Miłość [...] nie cierpi odwłoki”, to kalka gnomy „Amor odit inertes” ze Sztuki kochania. Zob. komentarz wydawcy ad locum w edycji: J. Ko ch anow s ki, Poematy okolicznościowe. Oprac. R. Kr zywy. Warszawa 2018, s. 131.

16 B. A w i a n ow i c z, „La istoria della casta Susanna” Lucrezii Tornabuoni - możliwe źródło „Zuzanny” Jana Kochanowskiego. „Europa Orientalis” t. 35 (2016), s. 468-469. 
nowożytnych (i wcześniejszych) twórców, dla których naturalne było wówczas przekształcanie "opracowywanego" pierwowzoru, dokonywanie amplifikacji, skrótów oraz szeroko rozumianych zmian" (s. 74-75, przypis 53). W swojej książce dowodzę czegoś wręcz przeciwnego, twierdzę bowiem, że postępowanie Kochanowskiego pozostaje w całkowitej zgodzie $z$ ówczesnymi praktykami. Nie uważam natomiast, żeby te poszerzenia świadczyły o wyjątkowym kunszcie, gdyż należały one do podstawowych umiejętności absolwentów szkół renesansowych (i w konstruowaniu deskrypcji wprawiano się podczas wstępnych ćwiczeń retorycznych).

Zestawiając utwór Kochanowskiego z przeróbką dokonaną przez Tornabuoni, Awianowicz wykazał charakterystyczne podobieństwa między oboma poematami „w miejscach, gdzie odchodzą one nieco od materii biblijnej lub (częściej) ją uzupełniaja" ${ }^{17}$. Przeprowadzona przez niego analiza porównawcza dowiodła, że już Tornabuoni wprowadziła choćby obszerniejszą ekfrazę ogrodu, w analogiczny sposób ukształtowała też scenę nagabywania przez starców. Rozpoznanie komparatystyczne nie umożliwia wprawdzie uznania polskiej Zuzanny za imitację czy parafrazę, lecz jak najbardziej pozwala widzieć w niej „emulacyjną grę” ${ }^{18}$. Jakkolwiek było, nie da się nie zauważyć, iż włoska arystokratka kierowała się analogicznymi założeniami artystycznymi, ponieważ - tak jak poeta z Czarnolasu - reprezentowała zbliżony, wypracowany przez humanistów model twórczości.

Za tym, że chcąc wzbogacić biblijną historię, Kochanowski szukał inspiracji, przemawia też, zdaniem Vincưrkovej, następująca fraza:

Żywie Bóg na niebie, który karze ludzkie złości,

A dobre ma na swej pieczy i każdego broni. [w. 2-3]

Badaczka dostrzega w owych słowach podobieństwo do fragmentu Żywota Józefa Mikołaja Reja ${ }^{19}$. Wskazując ponadto zbieżności treściowe, przyjmuje, że mogą one świadczyć o inspirowaniu się Kochanowskiego dramatem misteryjnym Nagłowiczanina, a w związku z tym o „kalwińskich wpływach występujących w Zuzannie" (s. 74), choć dopuszcza też możliwość czerpania przez obu pisarzy z tej samej tradycji literackiej.

Jak się okazuje, intuicja nie oszukała autorki artykułu jedynie w ostatnim przypuszczeniu. Otóż wspólnym źródłem myśli Reja i Kochanowskiego jest Księga Psalmów. Na to, że wstępna partia poematu stanowi wyraźną stylizację psalmiczną, zwróciła uwagę Kwiryna Ziemba, choć nie uzasadniła swej konstatacji w żaden sposób ${ }^{20}$. Uwzględniając również wers 1 utworu („Niechaj się źli nie kochają w swojej wszeteczności”), wskazać możemy wersety biblijnej księgi, które później trafiły też do Psałterza Dawidowego. Mam na myśli dotyczący Bożego miłosierdzia i Bożej sprawiedliwości Psalm 88, któremu w parafrazie Kochanowskiego odpowiada

19 Zob. M. Rej, Żywot Józefa. W zb.: Dramaty biblijne XVI wieku. Oprac., wstęp, przypisy K. W ilc zew s ka. Lublin 2000, s. 228: „Żyw ten Pan Bóg na niebie, który w to ugadza, / Iż każdemu prawemu sowito nagradza” (w cytacie wprowadzono poprawny układ wersów, które Wilczewska zachowawszy zapis starego druku - poszatkowała, rozdzielając pary rymowe).

Ibidem, s. 472.

Ibidem.

Zi e m ba, op. cit., s. 115 . 
Psalm 89. W zbieżnym fragmencie zachował poeta nawet identyczne jak w Zuzannie słowa w klauzulach:

A gdzie by dzieci jego Zakon mój wzgardziły

Ani posłuszne memu rozkazaniu były,

Onić kaźni nie ujdą za swe w szeteczności

I odniosą zapłatę godną swoich złości.

Ale jemu [tj. pobożnemu] zachowam miłosierdzie swoje

A nie będą omylne nigdy słowa moje. [w. 55-60; podkreśl. R. K. $]^{21}$

Fraza „Żywie Bóg na niebie” wydaje się echem sformułowania z Wulgaty: „Dominus in caelo sedis eius" (Ps 10, 5), które w spolszczeniu poety uzyskało postać: „Przedsię Bóg jest na niebie” (11, w. 7). Co ważne, słowa te - wyrażające pewność co do istnienia najwyższej instancji, która wymierza niechybną sprawiedliwość padają w kontekście myśli korespondujących z przesłaniem Zuzanny 22 .

Z kolei wersy 3-4 Zuzanny („A dobre ma na swej pieczy i każdego broni, / Kto się jeno pod zwyciężną Jego rękę skłoni”) to pogłos słów z wersetu 6 Psalmu 13, które pod piórem Kochanowskiego - w Psalmie 14 - przybrały postać zapewnienia:

Ale Pan każdego broni,

Kto się pod cień Jego skłoni. [w. 23-24]

Także rozpatrując te nawiązania, daleki jestem od tego, by posądzać poetę o zamiar popisywania się kunsztem. Temat Bożej sprawiedliwości w naturalny sposób kierował Kochanowskiego ku powszechnie znanej Księdze Psalmów i skłaniał do poetyckiego sparafrazowania zawartych w niej twierdzeń ${ }^{23}$.

Starania, które moja oponentka skłonna jest uznać za przejaw maestrii świadczącej o wysokiej kulturze literackiej, tłumaczą się podstawowymi umiejętnościami twórczymi, właściwymi poziomowi ówczesnego wykształcenia. Autor posłużył się nimi nie bez talentu, lecz i bez szczególnych zabiegów, które dowodziłyby wyjątkowych aspiracji artystycznych. Gdy zestawić poemat $\mathrm{z}$ wymienionymi dziełami jego pióra czy z drukowaną razem z Zuzanna pieśnią Czego chcesz od nas, Panie... (nie wspominając już o cyzelowanym pieczołowicie Psałterzu Dawidowym), różnica jest aż nadto widoczna. Rzecz jasna, ocena walorów tego czy innego utworu pozostaje zawsze do pewnego stopnia subiektywna, mimo to jednak nie sądzę, by podane przez

21 Fragment odpowiada wersetom 31-35 z Wulgaty.

22 Zob. 11, w. 7-8: „Przedsię Bóg jest na niebie, a stamtąd wszystko widzi, / Sprawiedliwych doświadcza, nieprawymi się hydzi”. Psalmiczna geneza przekonania afirmowanego w poemacie jest bardzo wyraźna. Por. wybrane fragmenty Psatterza Dawidowego dotyczące działania Opatrzności: „Pan bowiem sprawiedliwych na wszelki czas broni, / A przewrotne, złe ludzi cicha pomsta goni” (1, w. 19-20); „Bo będąc sprawiedliwym sprawiedliwość miłuje, / A dobre ludzi okiem łaskawym opatruje” (11, w. 11-12); „Bo to rzecz pewna, że ludzie złośliwi / Zaginać muszą, ani ich Bóg żywi” (37, w. 21-22); ,Sprawiedliwego nigdy Pan nie odstępuje” (55, w. 46); ,Pan strzeże sprawiedliwych / I broni od złośliwych" (97, w. 49-50).

23 Zestawienie paralelnych cytatów z Zuzanny i z Psatterza Dawidowego stanowi, być może, wskazówkę, że Kochanowski już na początku lat sześćdziesiątych zaczął myśleć o tłumaczeniu biblijnej księgi. 
Vincůrkovą argumenty, mające przemawiać za kunsztownością poematu, były dobrane trafnie.

\section{Rezyduum oralne jako hipoteza nie zawsze konieczna}

Od czasu, gdy w 1992 r. ukazał się polski przekład książki Waltera J. Onga (Oralność i piśmiennośc), badanie dominant twórczości oralnej w zabytkach literatury polskiej stało się oczywistością. Sugestywne twierdzenia amerykańskiego jezuity uzmysłowiły bowiem, że jeśli chodzi o powstawanie i percepcję, teksty prymarnie przeznaczone do obiegu ustnego są uwarunkowane inaczej niż układane $z$ myślą o druku teksty z okresu piśmiennego. Według Onga pierwszą i drugą grupę różnią nie tylko geneza i sposób odbioru, ale także to, jak reprezentujące je teksty odwzorowują mentalność twórców (choćby ich nawyki poznawcze). $Z$ pewnością kwestie te nie zostały dotąd przez naukę należycie wyjaśnione.

Jak dobrze wiadomo, alfabetyzacja społeczeństw europejskich nie spowodowała zaniku obiegu oralnego, będącego w wiekach średnich podstawowym sposobem wykonywania poezji (zwłaszcza wernakularnej), a wynalezienie i upowszechnienie się druku nie od razu doprowadziło do zaniku obiegu rękopiśmiennego i do ograniczenia roli żywego słowa w życiu społecznym. Hanna Dziechcińska, nie znając jeszcze koncepcji Onga, traktowała żywotność komunikacji ustnej w XVI i XVII w. jako kontynuację tradycji średniowiecznej, wynikającą z potrzeb życiowych:

oralno-audytywne środki komunikacji [...] były w istocie wręcz społeczną i kulturową koniecznością, już choćby tylko ze względu na trudności w obiegu przekazów drukowanych, z racji ograniczonego stopnia alfabetyzacji ówczesnego społeczeństwa, nie mówiąc nawet o niezbędnych w życiu politycznym i kościelnym walorach perswazyjno-dydaktycznych, jakie zawierała w sobie wypowiedź oralna skierowana do audytorium, posiadająca zatem przewagę nad przekazem drukowanym ${ }^{24}$.

Z kolei Ludwika Ślękowa, która także odniosła się do polskiej kultury wczesnonowożytnej, zauważyła:

W [...] stuleciach [XVI i XVII] „głoszenie” poezji odbywać się [...] mogło w oparciu o tekst drukowany, rękopiśmienny bądź wyuczony na pamięć z któregoś z tych przekazów. Było to dziedzictwo ery przedtypograficznej, kiedy możliwość lektury wzrokowej wśród ludzi wykształconych ograniczała, z jednej strony, dostępność rękopisów, z drugiej zaś - trudności związane z odczytywaniem odręcznego pisma ${ }^{25}$.

Stwierdzenia te uzmysławiają duży zasięg oraz wielorakość zarówno form przekazu literatury, jak i możliwości odbiorczych (cicha lektura, odczytywanie na głos wobec audytorium, wykonywanie z pamięci). Ong przekonuje, że zwłaszcza kultura rękopiśmienna pozostawała na usługach odbioru audialnego. Rozpowszechnienie druku ograniczyło ten typ komunikacji, choć nie stało się to od razu ${ }^{26}$.

W Rzeczypospolitej podtrzymaniu obiegu ustnego sprzyjała kultura szlachecka (w mniejszym zaś stopniu - naśladująca ją - mieszczańska), której ważnym składnikiem były popisy oratorów podczas zaślubin lub pogrzebów czy też recytowanie

H. D zi e c h cińs ka, Oglądanie $i$ stuchanie $w$ kulturze dawnej Polski. Warszawa 1987, s. 63.

L. Ślę k o w a, Formy przekazu a formy odbioru poezji w czasach renesansu i baroku. W zb.: Wiedza o literaturze i edukacja. Księga referatów Zjazdu Polonistów, Warszawa 1995. Red. T. Mi ch ałowska, Z. Goliński, Z. J a rosiński. Warszawa 1996, s. 278.

Ong, op. cit., s. 162-164. 
wierszy i opowiadanie facecji w trakcie spotkań towarzyskich. Podstawową dokumentację tych zjawisk zawierają sylwy szlacheckie - a więc manuskrypty. Także kultura popularna była otwarta na żywe słowo. Dla przykładu: tzw. druki jarmarczne dostarczały repertuaru wędrownym śpiewakom, wykonującym z pamięci pieśni religijne, nowiniarskie, historyczne itp. Zdarzało się, że pieśni takie wtórnie zapisywano. Część z nich przeniknęła do kultury ludowej, o czym z kolei świadczą materiały zebrane przez folklorystów. Dzięki źródłom pisanym wiemy, iż w obiegu ustnym owe utwory były poddawane znaczacym modyfikacjom ${ }^{27}$.

Wspomniane zjawiska nie zostały dotąd zadowalająco omówione. Jakkolwiek świadomość ich rangi nie jest badaczom dawnej literatury obca, nie pokuszono się jeszcze o ujęcie panoramiczne. Polskie prace $z$ tego zakresu można, $z$ grubsza rzecz ujmując, podzielić na powstałe „przed Ongiem” i „po Ongu”. Pierwsze w niewielkim stopniu odwołują się do aparatu pojęciowego wypracowanego głównie przez filologów klasycznych na potrzeby opisu poezji funkcjonującej prymarnie w obiegu ustnym, przede wszystkim poezji epickiej (do czego asumpt dały - jak wiadomo - pionierskie badania Milmana Parry'ego i Alberta B. Lorda nad pieśniami bałkańskich guślarzy), choć przecież takie kategorie, jak styl formularny, brak kanonicznej postaci tekstu czy zabiegi mnemotechniczne, były badaczom dobrze znane ${ }^{28}$. Polskich literaturoznawców zajmujących się piśmiennictwem epok dawnych "przed Ongiem” interesował raczej kulturowy wymiar zjawiska, oralno-audialne sytuacje komunikacyjne oraz spokrewnione $z$ nimi odmiany prozy i poezji (np. perswazja polityczna, kaznodziejstwo, liczne gatunki panegiryczne, formy ludyczne) bądź to, jak wykształcenie retoryczne przekładało się na kształt i popularność owych odmian ${ }^{29}$.

Natomiast prace powstające po publikacji przekładu książki amerykańskiego uczonego - który korzystając z ustaleń na temat twórczości z okresu przedpiśmiennego oraz na temat wpływu pisma i druku na procesy noetyczne czy komunikacyjne, usystematyzował wiele zagadnień łączących się $z$ tą problematyką - cechuje swego rodzaju entuzjazm metodologiczny. Polega on na wykazywaniu powiąania rozmaitych tekstów z tzw. rezyduum oralnym. Kategorie wyszczególnione przez Onga (lub przez jego poprzedników) traktuje się jako narzędzia opisowe i przykłada zarówno do twórczości, która z pewnością była kolportowana ustnie, jak i do takiej, którą określa się mianem „wtórnie oralnej”, powstałej już w okresie piśmiennym bądź typograficznym, lecz podtrzymującej pamięć konwencji i zachowań właściwych wykonaniu ustnemu. Nie zawsze wyniki tych prób są przekonujące. Podczas lektury należących do tego nurtu prac odnosi się nieraz wrażenie, że stosowane przez

Zob. J. Krzyża now ski, Pieśni popularne. W: Szkice folklorystyczne. T. 2: W kręgu pieśni. W krainie bajki. Kraków 1980, s. 23-24. Niedawno odnotowano, że na Podlasiu podczas sąsiedzkich obrzędów pogrzebowych wciąż śpiewa się średniowieczną Pieśń o św. Jopie, która trafiła do folkloru w XVII stuleciu, a później weszła do popularnych kancjonałów. Wykonywana jest ona zarówno na podstawie zapisu, jak i z pamięci. Zob. J. Da nielska, Pieśni o św. Hiobie - tradycje i trwanie. „Terminus” 2010, z. 1, s. 27-34.

28 Do charakterystyki obiegu polskiej twórczości średniowiecznej zużytkował je J. Woronczak $\mathrm{w}$ - pozbawionej niestety przypisów - pracy Typy przekazu tekstów średniowiecznych (w zb.: Pogranicza i konteksty literatury polskiego średniowiecza. Red. T. M i c h ał o w s k a. Wrocław 1989). Poza cytowaną książką D zi i c h c iń s ki ej (op. cit., s. 62-82, 155-212) zob. studia zebrane w tomie Kultura żywego słowa $w$ dawnej Polsce (Red. H. D zi e c h cińs ka. Warszawa 1989). 
badaczy instrumentarium zwykle sprawia, że dochodzą oni do zbliżonych wniosków, co stanowi konsekwencję m.in. posługiwania się ograniczonym repertuarem kategorii określających cechy swoiste twórczości oralnej: formularność, przedstawianie sytuacji typowych (narada, uczta, sceny militarne), bohater „ciężki”, skupienie się na działaniach postaci, paralelne konstrukcje, częsta składnia addytywna, napięcie agoniczne itd. ${ }^{30}$ Jakkolwiek czasem nie sposób odmówić takim przedsięwzięciom pomysłowości, to jednak traktowanie Ongowskiego zestawienia właściwości jako niemalże modelu eksplanacyjnego przypomina błędne koło, gdyż pozwala „udowodnić" oralny charakter prawie każdego dawnego tekstu (wszak sporo wskazywanych cech uzyskało rację bytu w teorii i praktyce wymowy, a część została utrwalona w konwencjach poetyckich, przez co ich związek z oralnością zwyczajnie się zatarł).

W tę inklinację badawczą wpisuje się postępowanie analityczne Vincůrkovej, która przekonuje, że Kochanowski celowo nawiązał do właściwości pieśni wernakularnych funkcjonujących w obiegu ustnym i że uczynił to, aby zbliżyć swą parafrazę do oczekiwań odbiorczych adresatki. Kardynalnym argumentem przemawiającym za takim domniemaniem jest sformułowanie $z$ prologu:

Kto nie ma nic pilniejszego, niech posłucha mało,

A ja powiem dostatecznie, jako się co zstało. [w. 21-22]

Wyrażona w tych wersach myśl przypomina spotykaną w niektórych poematach hagiograficznych (np. w Legendzie o św. Aleksym) czy w innych tekstach (Rozmowa Mistrza Polikarpa ze Śmiercia, Lament świętokrzyski, Wiersz o zachowaniu się przy stole) formułę służącą przywołaniu osób obecnych do wysłuchania utworu ${ }^{31}$. Badacze renesansowego poematu już dawno zwrócili uwagę, że podobne przyzwanie występuje w ułożonej oktawą Istoria di Susanna e Daniello (wariant tytułu: Historia di Susanna, moglie di Giouacchino), anonimowym utworze XV-wiecznym, który po przeróbkach kolportowano aż do początków XVII stulecia (wydania najbliższe studiom padewskim Kochanowskiego: 1543 i ok. 1550) w postaci niekosztownego druku dla pobożnych odbiorców ${ }^{32}$. Słowa skierowane do audytorium brzmią w tym tekście następująco:

Chi si diletta nuove cose udire

sia colla mente al mie parlare attento;

ch' io son venuto qui per proferire.

Nadmienić należy, że amerykański polihistor budował swą koncepcję korzystając obficie z twierdzeń historyków komunikacji (choćby kontrowersyjnego M. McLuhana) oraz z prac filologów klasycznych. W Oralności i piśmienności widać zwłaszcza duży wpływ E. A. Havelocka, którego wszak krytykowano za to, że jego wnioski opierały się na zbyt słabych przesłankach - zob. np. J. Halve r s o n, Havelock on Greek Orality and Literacy. „Journal of the History of Ideas” 1992, nr 1. Wiele elementów Ongowskiej charakterystyki stylu oralnego wciąż jest zreszta przedmiotem dyskusji.

31 Formuly te omawia T. Mich ałow ska (Między słowem mówionym a pisanym. W: Mediaevalia $i$ inne. Warszawa 1998, s. 112-125).

32 Na utwór zwrócił uwagę J. Krzyża nowski w studium Romans polski wieku XVI z 1934 r. (korzystam ze wznowienia: Warszawa 1962, s. 187-189). Rozpoznania uczonego doprecyzował Zi o m ek (op. cit., s. 125-126, 130, 131-132), powołując się na ustalenia włoskiego wydawcy (A. Pa r u c c i, La „Istoria di Susanna e Daniello”. Poemetto popolare italiano antico. „Romania” nr $165\langle 1913\rangle$, s. 54), który przypuszczał, że popularny druk stanowi przeróbkę starszego poematu autorstwa Niccola Cieca d'Arezzo (zm. po 1410). 
[Kto uwielbia słuchać nowych rzeczy,

Niech umysł zwróci bacznie ku moim słowom,

Gdyż przybyłem tu, by wieszczyć. $]^{33}$

Vincůrková ignoruje ewidentne podobieństwo między obu alokucjami, mimo że jej poprzednicy wskazali także inne „miejsca wspólne” we włoskim i w polskim poemacie $^{34}$. Nie jest to przemilczenie obojętne. Jeśli bowiem zgodzić się $z$ twierdzeniem, iż Kochanowski odwołał się do obcego tekstu drukowanego, wówczas koncepcja, wedle której poeta zamierzał imitować ustną twórczość hagiograficzną, okazuje się problematyczna. Trzeba by bowiem przyjąć, że naśladował on sformułowanie nie tyle znane - zarówno sobie, jak i adresatce dedykacji - ze słuchu, ile spetryfikowane we włoskim poemacie (w którym mogło się oczywiście znaleźć dzięki tamtejszej tradycji oralnej). Nie oznacza to, że oboje nie znali takich pieśni $z$ autopsji, lecz nic pewnego na ten temat nie wiemy. Aby uniknąc komplikacji, badaczce było zatem wygodniej - jak można się domyślać - sprawę podobieństw w ogóle pominać. Ale jest to nadużycie.

Rozpatrując typ bohaterki, zgadza się Vincůrková ze mną, że Zuzanna reprezentuje jedną zasadniczą cechę: cnotliwość stanowiącą konsekwencję pobożności. Niemniej zarzuca mi, że w swojej analizie nie uwzględniłem faktu, iż „Przypisywanie bohaterom stałych cech (lub zespołów cech) wywodzi się z oralnych technik pamięci” (s. 76; zob. też przypis 59 i 62), którego to faktu przejawem ma być m.in. łączenie $z$ ich imionami epitetów stałych, „określających najistotniejszy (dla przebiegu fabuły) rys ich charakteru i pełniących zarazem funkcje mnemotechniczne” (s. 76). Konstatacje te opatrzyła autorka odesłaniami do ksiażki Onga, który swoje obserwacje formułował przede wszystkim na podstawie ustaleń filologów dotyczących poematów Homerowych.

Takie mechaniczne adaptowanie stwierdzeń Onga do opisu poematu z XVI w. jest niepoważne. Już abstrahując od tego, że choćby w Odysei świniopas Eumajos nazywany bywa „boskim pastuchem”, co każe z większą ostrożnością traktować twierdzenia zarówno na temat zgodności stałych epitetów $\mathrm{z}$ charakterem postaci, jak i na temat motywacji fabularnych dla tego rodzaju formuł ${ }^{35}$, zauważyć należy, że bohaterka poematu Kochanowskiego nie jest charakteryzowana za pomoca stałych określeń. Autor uznał ją natomiast za postać egzemplaryczną, której losy maja dowodzić sformułowanej na wstępie tezy:

Wielką moc takich przykładów w historyjach mamy

I sami tego na oko często doznawamy. [w. 5-6]

Istoria di Susanna e Daniello. W: Pard u c c i, ed. cit., s. 55 (oktawa 1, w. 1-3).

Zob. Krzyża now ski, Romans polski wieku XVI, s. 188: „Zbieżności są tak uderzające, iż bez popełnienia przesady przyjąć można, że Kochanowski Historię włoską czytał lub nawet, co nie jest wykluczone, słyszał ją śpiewaną na ulicy któregoś z miast włoskich”. Zaznaczyć należy, że podobieństwo dotyczy jedynie konkretnych sformułowań, gdyż utwór Kochanowskiego podporządkowany został odmiennym założeniom.

Przykład z Eumajosem przywołuje jako jaskrawy, zdając sobie oczywiście sprawę, że problem pochodzenia i funkcji tzw. języka formularnego jest o wiele bardziej skomplikowany i że dyskusja nad nim wciąż trwa. Zob. choćby $\mathrm{K}$. Z i e li ń s k i, „Iliada” i jej tradycja epicka. Studium z zakresu greckiej tradycji oralnej. Wrocław 2014, s. 27-31, 346-348. 
Bohaterke potraktował autor jako przykład dowodzący twierdzenia ogólnego, zatem naturalne winno być skojarzenie $z$ retorycznym egzemplum (por. definicję Kwintyliana: „Przywołanie jakiegoś przeszłego zdarzenia, rzeczywistego lub domniemanego, które może służyć przekonaniu audytorium o prawdziwości przedstawianej przez nas kwestii”36), które jak najbardziej mogło czerpać $z$ historii, a Kochanowski uważał wszak Zuzannę za osobę historyczną. Jak zaznacza Heinrich Lausberg, najpowszechniejsze i najbardziej wiarygodne sa przykłady historyczne, ponieważ opieraja się na prawdzie ${ }^{37}$. Przybierały one różnorodne formy podawcze, m.in. narracyjna ${ }^{38}$. Aby wymowa sfabularyzowanego przykładu była przejrzysta, jego bohater nie mógł ucieleśniać zbyt wielu cech (pozytywnych czy negatywnych), gdyż nie przysłużyłoby się to perswazji.

Utwory wierszowane przedstawiające postaci egzemplaryczne były mniej sformalizowane (nie obowiązywała w nich ścisła logika oracji). Ambitniejsi poeci chętnie odwoływali się do konwencji znanych z epiki klasycznej, widząc w niej repozytorium charakterystycznych scen, postaci, wypowiedzi, ekfraz itp. Ich wzorce utrwalił zapis eposów Homera, a spopularyzowała Eneida Wergiliusza. Po przykłady z poezji nierzadko sięgali retorzy w celach poglądowych, poeci zaś nie stronili od stosowania wskazówek nauczycieli wymowy. Twórczość pierwotnie ustna (epika homerycka) miała swój wpływ na poetów piszących oraz na mówców, a ci z kolei inspirowali siebie nawzajem. Także układane wierszem żywoty świętych w językach narodowych kształtowane były przez rozmaite konwencje i wzorce literackie, którymi posługiwali się ich autorzy. Często przywoływana przez Vincưrkovą Legenda $o$ św. Aleksym - tekst niewątpliwie funkcjonujący w wiekach średnich w obiegu ustnym - czerpie, jak starałem się tego dowieść w innym studium, z topiki biograficznej (w początkowej partii fabuły) i romansowej (w części przedstawiającej życie dorosłe) ${ }^{39}$. Scena rozstania Aleksego i Famijany to hagiograficzny odpowiednik porzucenia Dydony przez Eneasza (obaj bohaterowie - Aleksy i Eneasz - rezygnują ze szczęścia osobistego w imię racji wyższych). Nie trzeba dodawać, że konstruując ten wątek, Wergiliusz nawiązał do wcześniejszych eposów.

W moim przekonaniu nie sposób z tego oralno-epicko-retorycznego dziedzictwa wypreparować cech modelowych, które mogłyby służyć do prostych rozróżnień - jak próbuje to czynić autorka artykułu. Twierdzi ona przykładowo, powołując się ponownie na Onga, że twórczość ustna skupia się na czynach, nie na wyglądzie przedmiotów czy osób (s. 76). W Zuzannie jednak opisuje się i miejsca, i bohaterkę. Dalej badaczka nadmienia: „Protagoniści utworów należących do tej tradycji często są wręcz tożsami ze swoimi działaniami” (s. 76). Twierdzenie to można odnieść do tylu rozmaitych utworów (również autorstwa Kochanowskiego), że jako kryterium przestaje mieć ono większy sens.

Podobnie w przypadku cech bohaterów, których Ong nazwał „postaciami cięż-

Cyt. za: H. La u s b e rg, Retoryka literacka. Podstawy wiedzy o literaturze. Przekł., oprac., wstęp A. Gorzkow ski. Bydgoszcz 2002, s. 252.

A. 253

Zob. J. Zi o mek, Retoryka opisowa. Wyd. 2, popr. Wrocław 2000, s. 107-108, 110.

Szerzej na ten temat zob. R. Kr zy wy, Topika i idea. Narratologiczna lektura „Legendy o św. Aleksym”. „Ruch Literacki” 2006, z. 3. 
kimi”, rozumiejąc przez to głównie herosów, „których czyny mają charakter monumentalny, pamiętny i zazwyczaj publiczny" ${ }^{40}$. Pojęcie to - o czym Vincůrková zdaje się nie wiedzieć - obejmuje swym zakresem typ postaci, który autorzy renesansowych poetyk określali łacińskim terminem „persona gravis”. Juliusz Cezar Scaliger, podsumowując pewną tradycję rozważań retorycznych i poetyckich na temat twórczości panegirycznej, skonstatował, że owa kategoria dotyczy osób wysoko postawionych w hierarchii społecznej, tj. - poza bogami - herosów, królów, książąt i obywateli pełniących służbe publiczną, a jako odpowiedni do ich wysławiania wskazał styl podniosły ${ }^{41}$. Wynika $z$ tego, że ten typ bohatera nie jest właściwy wyłącznie twórczości oralnej, lecz w ogóle określonym odmianom literatury: eposom heroicznym i historycznym, epicediom układanym prozą, wierszowanym panegirykom, ale również licznym tekstom należącym do piśmiennictwa hagiograficznego - czy to wierszowanego, czy prozatorskiego (wielu średniowiecznych świętych wywodzi się $z$ rodów zamożnych). Podane przez autorke przykłady św. Aleksego i św. Doroty (s. 77-78) potwierdzają ten stan rzeczy, lecz bynajmniej nie dowodzą, że Kochanowski chciał dostosować przedstawienie Zuzanny do frazeologii i sposobu obrazowania typowych dla wernakularnych pieśni hagiograficznych. Zarówno jej status społeczny, jak i cudowna ingerencja Boga, który to motyw badaczka również łączy z oddziaływaniem owej twórczości, wynikają bezpośrednio $\mathrm{z}$ opowieści zawartej w Księdze Daniela, nie $\mathrm{z}$ domniemanych zabiegów poety ${ }^{42}$. $Z$ tego samego powodu nietrafiona jest uwaga, iż w Zuzannie „uwidacznia się oralna zasada nieopisywania postaci niedziałajacych" (s. 78). Poeta zwyczajnie nie wprowadzał charakterystyk, którym brakowałoby odpowiednika w Piśmie Świętym, twórczość hagiograficzna nie ma tu nic do rzeczy. Gdyby autor kierował się rzeczywiście „swoistą ekonomia przekazu" (s. 78), nie wprowadzałby przecież żadnych amplifikacji.

Nie przekonują też próby powiązania innych składników świata przedstawionego Zuzanny z wierszowaną hagiografią. Domniemywa choćby autorka, że określenie proroka Daniela w poemacie mianem „dziecięcia” (w. 169) stanowi celowe odwołanie się do „pamięci kulturowej rodzimych odbiorców, znających typową formę żywotów świętych" (s. 81), gdyż w Wulgacie występuje w tym miejscu określenie wskazujące na młodzieńca, a dziecko w roli posłańca Bożego to z kolei postać przywodząca na myśl epizody z Legendy o św. Aleksym oraz z Legendy o św. Dorocie. Badaczka sugeruje nawet - w trybie warunkowym, co prawda - że być może " dziecię" jest dodatkowym bohaterem utworu" (s. 81) ${ }^{43}$. Pozostawiając na boku

Ong, op. cit., s. 102.

J. C. S c a li g e r, Poetices libri septem. [Lyon] 1561, s. 183-184 (IV 2). Korzystam z reprintu: Stuttgart - Bad Cannstatt 1964.

$\mathrm{Nb}$. omawiając w swojej książce charakter bohaterki poematu, stwierdziłem, że rozmija się on z renesansowymi wymogami co do protagonistów epiki podniosłej. Kobieta mogła być za to główną postacią poematu miłosnego, religijnego lub dydaktycznego, dla którego odpowiedni był styl średni bądź prosty (co zresztą uprawdopodobnia kojarzenie utworu z poetyckim egzemplum). Nie wywołuje to we mnie zdziwienia, jak sugeruje badaczka (s. 78). Definiowałem jedynie status postaci. I tym razem autorka imputuje mi pogląd, którego sam bym nie sformułował, a mianowicie że dziecko nie pasuje do „koncepcji Zuzanny jako "epiki eleganckiej»” (s. 82, przypis 82). Swoje stanowisko wyraziłem jasno i biorę za nie odpowiedzialność. Za to, co chciała zrozumieć autorka (bo nie śmiem jej podejrzewać o celową nierzetelność), nie mogę już odpowiadać. 
kwestię pamięci kulturowej polskich odbiorców, która jest cokolwiek nieuchwytna, muszę stwierdzić, że w tym miejscu wywodu Vincůrkovej uwidacznia się zwykłe myślenie życzeniowe. W biblijnej podstawie parafrazy tożsamość chłopca nie jest ukazana enigmatycznie, więc wątpię, by ktokolwiek mógł przypuszczać, że jest to ktoś inny niż Daniel. Określenie go jako dziecka spotykamy wszak w pierwszym pełnym polskim przekładzie Pisma Świętego, zwanym Biblia Leopolity. Podążając za litera Wulgaty, tłumacz oddał stosowny passus (Dn 13, 45) następująco: „A gdy ją już wiedziono na śmierć, wzbudził Pan ducha świętego dziecięcia młod z i u c h n e g o, któremu imię Daniel"44.

Przywołany przekład wyszedł w 1561 roku. Druk rozpoczęto jednak rok wcześniej, więc niewykluczone, że cały tom był gotów już w pierwszej połowie 1560 roku. Datę publikacji Zuzanny ustala się na „około 1562”45. Oznacza to, że utwór mógł być drukowany na przełomie lat 1561 i 1562, a z pewnością ukazał się przed śmiercią Elżbiety Radziwiłłowej (30 VI 1562). Czy Kochanowski korzystał z tego tłumaczenia? Zdarzają się istotne zbieżności, które w moim przekonaniu potwierdzaja taką ewentualność. Dla przykładu kilka paralelnych sformułowań:

- „widali ją starcowie na każdy dzień wchodząca” (Dn 13, 8) | „Starzy patrząc na każdy dzień, gdzie pani chodziła” (w. 47);

- „Ścisk na mię teraz zewsząd” (Dn 13, 22) | „Zewsząd ucisk przyszedł na mię” (w. 89);

- „Tedy zawołała głosem wielkim Zuzanna” (Dn 13, 34) | „I krzyknęła wielkim głosem" (w. 95);

- „Boże wieczny [...], który wiesz wszystko pierwszy, niż się stanie” (Dn 13, 42) | „Nieśmiertelny Panie, / Który wszystko wiesz i pierwej, niźli się co zstanie” (w. 161-162);

- „żądza wywróciła serce twoje” (Dn 13, 56) | „przeklęta twoja żądza serceć wywróciła” (w. 198).

Trzeba podkreślić, że Kochanowski nie parafrazował wersetów Biblii Leopolitypodażał bowiem za Wulgata - lecz jest wielce prawdopodobne, że miał ten przekład w ręku (zaprezentowane zestawienie to sugeruje) i za nim przyjął spolszczenie „puer iunior" z tekstu łacińskiego, które tak zafrapowało Vincưrkovą ${ }^{46}$.

Podobnie opis zbiorowego przeżywania emocji towarzyszącego oskarżeniu i skazaniu niewinnej bohaterki (s. 82) nie jest pomysłem Kochanowskiego, lecz znajduje odpowiednik w Księdze Daniela - a więc nie może być przejawem stylizacji na hagiograficzną pieśń wernakularną. Publiczne okazywanie silnych wzruszeń (płaczu,

Tu i dalej przekład cytuję według pierwodruku: Biblija, to jest Księgi Starego i Nowego Zakonu na polski język z pilnościa według łacińskiej Biblijej, od Kościoła krześcijańskiego powszechnego przyjętej, nowo wyłożona. Kraków 1561. Podkreśl. R. K.

45 K. Pi e ka r s k i, Bibliografia dzieł Jana Kochanowskiego. Wiek XVI i XVII. Wyd. 2, rozszerz. Kraków 1934, s. 67. Zob. też P. Bu chw ald-Pelc ow a, Dawne wydania dzieł Jana Kochanowskiego. Warszawa 1993, s. 30 (przypis 36), 258. - K. Ko r otaj ow a, W. Ko r o taj, Bibliografia dziet Jana Kochanowskiego. T. 1: XVI-XVII wiek. Warszawa 2001, s. 240 (maszynopis Instytutu Badań Literackich PAN).

46 Dodajmy, że w anonimowej Istoria di Susanna e Daniello (s. 69, 70) posłaniec Boży zostaje określony słowem ,fanciullino [chłopczyk]” (oktawa 47, w. 3), a lud nie ma wątpliwości, iż jest on „questo fanciullo che Daniello ha nome [chłopczykiem, który ma na imię Daniel]” (oktawa 51, w. 2). 
radości, uniesienia) w dawnej obyczajowości oraz adekwatne stylizowanie wzruszeń bohaterów literackich to zjawisko samo w sobie interesujacce ${ }^{47}$ - wiązanie go jednak wyłącznie $z$ kulturą oralną to spore uproszczenie. Nie dostrzegam również dążenia poety do „totalizacji doświadczeń bohaterów” (s. 82-83), o którym przekonywać ma nie wielo- (s. 82), lecz pięciokrotne użycie w narracji słowa „wszyscy” (w opowiadaniu o Zuzannie $z$ Biblii Leopolity występuje ono trzy razy, nie liczac synonimicznego „mnóstwo” w odniesieniu do ludzi), podobnie jak nie dostrzegam zabiegów poety zmierzających do tego, by nadać fabule charakter agonistyczny (s. 83) - taki kształt ma po prostu opowieść biblijna (oraz tysiące innych fabuł, także $z$ czasów nam współczesnych).

Za element „oralności świadomie wprowadzonej przez Kochanowskiego” (s. 83) uznała badaczka również motyw rodzimych gatunków drzew występujący w scenie weryfikacji prawdomówności lubieżnych sędziów (w poemacie zamiast pistacji i dębu z Wulgaty występują jabłoń i orzech). Zabieg ten skojarzyła z mechanizmem homeostazy, tj. ukazywaniu życia w „swoistej teraźniejszości” ${ }^{48}$, motywując go zamiarem adaptacji tekstu biblijnego do „horyzontu doświadczeń czytelników, w tym adresatki Zuzanny" (s. 83). Pozostawiając na boku kwestię, iż Ong nazywa homeostazą zupełnie coś innego (,pozbywanie się wspomnień, które przestały mieć znaczenie dla teraźniejszości”" ${ }^{49}$, zwrócić należy uwagę, że tego rodzaju zmiana wynikała raczej $z$ naturalizacji czy domestykacji tekstu wyjściowego, typowej w dawnych przekładach, niż z celów podanych w omawianym artykule ${ }^{50}$. W Biblii Leopolity pierwszy starzec zeznaje, że przyłapał kochanków „pod malina”, drugi - „pod śliwa”; w anonimowym utworze włoskim odpowiednio: „sotto un susino [pod śliwa]” (oktawa 53, w. 2) i „sotto un pin [...] sull' erba [pod sosna na trawie]” (oktawa 56, w. 2); u Tornabuoni: „sott'un ginepro [pod jałowcem]” (w. 322) oraz „sotto un pino [pod sosną)" (w. 340) ${ }^{51}$.

Ostatnią cechą poematu, którą Vincůrková łączy z twórczością przekazywaną ustnie, jest paralelność niektórych wersów, co może „kojarzyć się [...] z fragmentami średniowiecznych pieśni, gdzie paralelizmy pełniły np. funkcje mnemotechniczne" (s. 84). Przykładem ma być rzekome wyjaskrawienie przez Kochanowskiego występującej w Biblii analogii scen przesłuchania obu starców, a także powtórzenie myśli z początku utworu w jego zakończeniu. Drugi „paralelizm” to w moim przekonaniu wniosek podsumowujący narratio jako część argumentacyjną, dowodząca di P. Orvieto. Bergamo 1992, s. 49. Zob. też Zi o mek, O „Zuzannie” Jana Kochanowskiego, s. 137. 
tezy postawionej na wstępie (znów zasady retoryki są tu wystarczającą motywacją). Wątpię natomiast, by w ogóle Kochanowski dążył do imitowania powtórzeń z opowieści biblijnej w celu naśladowania twórczości ustnej. W Księdze Daniela pojawia się interesująca odpowiedniość w dwóch epizodach. Kiedy starcy zapałali pożądaniem do Zuzanny, „wywrócili rozum swój, a spuścili oczy swoje, aby nie widzieli nieba, ani pamiętali na sądy sprawiedliwe" (Dn 13, 9). Sytuacji tej odpowiada reakcja Zuzanny na położenie przez sędziów rąk na jej głowie, który to gest oznaczał uznanie jej za winną stawianych zarzutów: „płaczac, wejrzała w niebo, bo serce jej miało dufanie w Panie” (Dn 13, 35). Jak wyjaśnia egzegeta, odwrócenie wzroku od niebios podkreśla postępowanie wbrew Bożym nakazom, gest Zuzanny zaś tłumaczące się pobożnością zawierzenie sprawiedliwości (w tradycji biblijnej spoglądanie ku niebiosom stanowi synonim modlitwy) ${ }^{52}$. Kochanowski zupełnie zignorował ten znaczacy paralelizm. W opisie zachowania starców nie pojawia się charakterystyczne skierowanie wzroku, poeta zachował je tylko przedstawiając desperację Zuzanny (w. 143). Trudno przypuszczać, że pominąłby ową opozycję, gdyby przedmiotem jego starań było uwydatnienie tego rodzaju konstrukcji.

Prześledziłem dość uważnie wywód Vincůrkovej, by wykazać słabość jej argumentacji. W zasadzie jedynie charakterystyczną formułę o funkcji fatycznej można uznać za pozostałość twórczości oralnej - lecz już niekoniecznie za przejaw świadomego imitowania wernakularnych pieśni hagiograficznych $\mathrm{w}$ całym poemacie. Jestem skłonny twierdzić, że ów relikt frazeologiczny stanowi w Zuzannie wyraz dość częstego w okresie renesansu - zwyczaju odczytywania utworów poetyckich na dworach osób możnych bądź w gronie przyjaciół ${ }^{53}$. Kochanowski przewidywał taki typ odbioru dla swoich wierszy, o czym świadczą choćby słowa skierowanej do Jana Krzysztofa Tarnowskiego dedykacji z Szachów:

A ty się nie wstydź, masz li czas spokojny,

Przesłuchać tej to krotochwilnej wojny. [w. 23-24]

Także Zuzanna mogła być wykonywana w ten sposób. Jak sądzę, użyciu charakterystycznej formułki nie patronował zamiar nadania poematowi cech właściwych twórczości oralnej, stanowi ona raczej świadectwo częstej sytuacji wykonawczej viva voce w kręgach dworskich bądź humanistycznych. Czy poeta znał ją ze słuchu, czy zaczerpnął z włoskiego druczku - rozstrzygnać się nie da. Jeśli słuchacze rozpoznali jej rodowód, mogli uważać zabieg Kochanowskiego za całkiem zgrabny.

Niniejsza polemika uzmysławia wyraźnie słabości metodologiczne dociekań Vincůrkovej: absolutyzowanie stwierdzeń Onga (czy innych znawców twórczości ustnej) i traktowanie ich jako instrumentu pozwalającego wykazać istnienie rezyduum oralnego w analizowanym tekście; ignorowanie niewygodnych przesłanek tekstowych oraz faktu, że sporo konwencji swoistych dla poezji wykonywanej z pamięci zwyczajnie stała się częścią warsztatu pisarskiego; abstrahowanie w końcu od innych dzieł poety i od niewygodnych ustaleń z literatury przedmiotu. Dużym

Zob. M. P a r c h e m, komentarz w: Księga Daniela. Wstęp, przekł., koment. ... Częstochowa 2008, s. 710,717 .

53 Zob. W. N el s o n, From „Listen, Lordings” to „Dear Reader”. „University of Toronto Quarterly” t. 46 (1976-1977), nr 2, s. 110, 112-113, 117. - Ślę k ow a, op. cit., s. 274, 280-281. 
błędem jest również myślenie życzeniowe i brak należytego dystansu wobec importowanej i wciąż dyskutowanej koncepcji. Badaczka oralności wtórnej dostrzega głównie jej symptomy, nie próbuje zaś dociekać innych motywacji dla komponentów formalnych i treściowych poematu. Procedura taka prowadzi, niestety, do wniosków wątpliwej wartości.

\author{
Abstract \\ ROMAN KRZYWY University of Warsaw \\ ORCID: 0000-0001-9964-7362
}

\title{
JAN KOCHANOWSKI'S "ZUZANNA" ("SUSANNA") GOES ASTRAY TO ORAL CREATIVITY
}

The article contains a polemics with Dorota Vincůrková's theses formulated in her study Jan Kochanowski's "Zuzanna" ("Susanna") against the Vernacular Conventions of Hagiographic Songs ("Literary Memoir" 2018, issue 4). Contrary to Vincůrková's stance, the present author proves in the first part of the paper that it is hardly possible to state that the artistic means of expression employed by the Renaissance poet in his paraphrase of a fragment of The Book of Daniel provide for the artistry of the poem about Susanna. In the second part of the paper Krzywy undermines the validity of observations about Kochanowski's imitating the "typically" oral means of expression which might, in the view of Vincưrková, bring the poem closer to the popular hagiographic songs and to the intellectual horizons of Elżbieta Radziwiłłowa, de domo Szydłowiecka, to whom the poem is dedicated. The author of the paper proves that with the exception of one fragment which calls the audience to hear the story, the remaining means of expression belong to a set of conventional rhetoric-literary ones. He is also convinced that too little is known about the piece addressee's literary awareness to formulate theses about the artistic shape of Zuzanna (Susanna). 